
v4i1.2795

\title{
Respon Pupuk Organik Ampas Tahu dengan Bioaktivator Terhadap Pertumbuhan Ipomoea reptans
}

\author{
Fitri Sunarsih $\left.^{1 *}\right)$, Yetty Hastiana ${ }^{2)}$, Aseptianova ${ }^{2)}$ \\ ${ }^{1}$ Pendidikan Biologi FKIP Universitas Muhammadiyah Palembang \\ ${ }^{2}$ Dosen Pendidikan Biologi FKIP Universitas Muhammadiyah Palembang \\ *corresponding author \\ e-mail : fitrisunarsih@student.pps.unsri.ac.id
}

\begin{abstract}
Abstrak
Pupuk organik ampas tahu dengan bioaktivator mol tape singkong mengandung unsur makro yang berpotensi terhadap pertumbuhan kangkung darat (Ipomoea reptans). Penelitian ini bertujuan untuk mengetahui kandungan unsur makro pupuk organik ampas tahu dengan bioaktivator mol tape singkong pada konsentrasi yangr berbeda terhadap pertumbuhan kangkung darat (Ipomoea reptans). Penelitian di dilaksanakan di kebun biologi, uji hara pupuk organik dan tanah di laboratorium Baristand, metode Penelitian ini menggunakan rancangan acak kelompok (RAK) dengan 4 perlakuan dan 6 ulangan. Hasil penelitian ini menujukkan terdapat kandungan unsur makro pupuk organik ampas tahu pada Nitrogen terdapat $0,09 \%$, posfor $\left(\operatorname{sbg} \mathrm{P}_{2} \mathrm{O}_{5}\right.$ ) terdapat 0,62\% dan Kalium $\left(\operatorname{sbg} \mathrm{K}_{2} \mathrm{O}\right) 1,82 \%$. Dari hasil analisis sidik ragam terhadap tinggi tanam F-hitung perlakuan 2,769 lebih kecil dibanding $F$ tabel 0,05 (3,29) dan F tabel 0,01 (5,42), jumlah daun F-hitung perlakuan 6,284 lebih besar dibanding $F$ tabel 0,05 (3,29) dan F tabel 0,01 (5,42), lebar daun F-hitung perlakuan 17,40 lebih besar dibanding F tabel 0,05 (3,29) dan F tabel 0,01 (5,42), dan pada panjang daun F-hitung perlakuan 6,935 lebih besar dibanding F tabel 0,05 (3,29) dan F tabel 0,01 (5,42). Pemberian pupuk organik ampas tahu dengan bioaktivator sangat berpengaruh terhadap pertumbuhan kangkung darat (Ipomoea reptans)
\end{abstract}

Kata kunci: pertumbuhan, kangkung darat (Ipomoea reptans),pupuk organik,

\begin{abstract}
growth is a process increase the size, shape or volume. kale (Ipomea reptans L.) is a plant that lived and can grow more than one year. characteristic of kale is elliptic, has spacious, containing water (herbaceous) and potholes. the purpose of this study to determine the content of macro elements in organic fertilizers made from tofu and fermented cassava bio-activator mole on the growth of land kale (Ipomoea reptans, L). This study carried out on the garden in the UMP and test biological nutrient organic fertilizers and performed in the Baristand's laboratory. This research using randomized block design (RBD) with 4 treatments and 6 rans. the results of this study shows that it contains macro elements (CME) in soil and organic fertilizer pulp out with a bio-activator mol cassava with different concentrations, and test results significant difference (LSD) at treatment PO, P1, P2, and P3 showed highly significant the height, number of leaves, leaf width and length of the leaves on the plant kale land (Ipomoea reptans $L$ ).
\end{abstract}

Keywords:land kale growth (Ipomoea reptans) organic fertilizer.

\section{Pendahuluan}

Usaha yang dilakukan untuk memperbaiki kesuburan tanah adalah dengan melakukan pemupukan menggunakan pupuk organik (Rodiah, 2013) Pemupukan merupakan salah satu kegiatan yang penting dalam dalam budidaya untuk meningkatkan produktivitas tanman. Menurut Marpaung (2014), upuk organik adalah semua bahan organik yang berasal dari tanaman dan hewan yang dapat dirombak menjadi kandungan hara yang tersedia pada tanaman, pemberian pupuk organik pada tanaman merupakan suatu tindakan dalam pengelolaan yang dapat memperbaiki kesuburan tanah baik itu fisik,kimia dan biologi.

Pupuk organik dibuat melalui proses pengomposan, pengomposan pada pembuatan 
pupuk organik terjadi secara alami akan tetapi proses tersebut dapat dipercepat dengan bantuan bakteri pengurai berupa mikroorganisme lokal. Menurut Hermawan (2011), bioaktivator merupakan larutan yang mengandung mikroorganisme lokal yang bisa dibuat dari sampah rumah tangga dan membantu proses pengomposan. Dalam kaitannya dengan pembuatan pupuk organik dari ampas tahu maka biaktivator tentu akan sangat berperan dalam mempercepat proses pengomposan.

Kangkung merupakan merupakan jenis tanaman yang mudah dibudidayakan karena perawatannya sangatlah mudah. Menurut Salamah (2013), kangkung darat dapat ditanam di daerah yang beriklim panas maupun lembab, serta tumbuh baik pada tanah yang kaya bahan organik dan unsur hara yang cukup, sehingga dalam pembudidayaan kangkung membutuhkan pupuk untuk menoptimalkan pertumbuhan. Pada proses penanaman perlu adanya pemupukan Selain pemupukan dari luar, tanah telah menyediakan unsur hara dan mineral yang cocok untuk tanaman akan tetapi dalam jangka panjang persediaan hara dalam tanah semakin berkurang akibatnya terjadi ketidakseimbangan. Oleh karena itu pemupukan merupakan harus dilakukan dalam proses penanaman.

Berdasarkan uraian diatas peneliti akan melakukan penelitian dan tujuan dari penelitian ini yaitu untuk mengetahui kandungan unsur makro pupuk organik ampas tahu dengan bioaktivator mol tape singkong dan untuk mengetahui pengaruh pemberian pupuk organik pada konsentrasi yang berbeda terhadap pertumbuhan kangkung darat (Ipomoea reptans).

\section{Metode Penelitian}

Penelitian ini menggunakan metode ekperimen dengan Rancangan Acak Kelompok (RAK), dengan 4 perlakuan dan Gulangan, yaitu $\mathrm{P}_{0}: 3 \mathrm{~kg}$ tanah tanpa pupuk organik ampas tahu dengan bioaktivator mol tape singkong $\mathrm{P}_{1}$ : $3 \mathrm{~kg}$ tanah +100 gr pupuk organik ampas tahu dengan bioaktivator mol tape singkong, $\mathrm{P}_{2}: 3$ $\mathrm{kg}$ tanah +200 gr pupuk organik ampas tahu dengan bioaktivator mol tape singkong dan $\mathrm{P}_{3}$ : $3 \mathrm{~kg}$ tanah $+300 \mathrm{gr}$ pupuk organik ampas tahu dengan bioaktivator mol tape singkong.

\section{Waktu dan Tempat}

Penelitian ini dilakukan pada bulan Oktober 2014 sampai Februari 2015 dan penelitian ini di dilaksanakan di kebun biologi dan uji hara pupuk organik dan tanah di uji di laboratorium Baristand.

\section{Alat dan Bahan}

Alat yang di gunakan dalam penelitian ini adalah: 24 buah polybag berukuran $40 \times 50 \mathrm{~cm}$, timbangan, sekop, penggaris, kamera, alat tulis dan sarung tangan.

Bahan yang digunakan dalam penelitian ini: benih kangkung darat, pupuk organik ampas tahu sebanyak $20 \mathrm{~kg}$, mikroorganisme lokal sebanyak 1 liter, dedak sebanayk $2 \mathrm{~kg}$,tanah dan air secukupnya.

\section{Cara Kerja}

\section{a. Pembuatan Pupuk Organik Limbah Am- pas Tahu}

Ampas tahu diperas dan dikeringkan terlebih dahulu selama 4 hari (sesuai dengan cuaca atau sampai tidak terdapat larva serangga pada ampas tahu tersebut) untuk mengurangi kadar airnya. Kemudian setelah kering campurkan, campurkan dedak atau bekatul sebanyak $2 \mathrm{~kg}$ dan yang terakhir campurkan mol tape singkong sebanyak $75 \mathrm{ml}$. Proses fermentasi akan berlangsung selama 14 sampai 29 hari karena dibutuhkan waktu untuk menetralisir minyak yang terkandung dalam ampas tahu. Kompos yang sudah matang ditandai dengan warna coklat kehitaman dan tidak bebau. Selain itu, kompos siap dipakai (Untung, 2014).

Menurut Farhana (2013), salah satu bahan yang dapat digunakan sebagai bahan baku pembuatan pupuk organik adalah limbah tahu, baik limbah padat maupun cair. Limbah yang dihasilkan pabrik tahu berupa kulit kedelai, ampas, dan air tahu masih dapat dimanfaatkan menjadi produk-produk yang bermanfaat. 
Pada proses pengolahan tahu akan dihasilkan lim “'”bah berupa ampas tahu yang apabila tidak segera ditangani dapat menimbulkan bau tidakyang tidak sedap.

\section{b. Parameter Yang Diamati Dalam Peneli- tian Adalah:}

1) Lebar Daun

Lebar daun dihitung dengan mengukur bagian daun tanaman terlebar dan dihitung dengan satuan centimeter (cm).

2) Jumlah Daun (helai)

Jumlah daun dihitung dengan cara mengurangkan data akhir penelitian dengan data awal penelitian.

3) Panjang Batang

Panjang batang tanaman dihitung dari pangkal batang sampai ujung titik tanaman.

\section{HASIL}

1. Data Hasil Analisis Kandungan Mikro Tanah danPupuk Organik Ampas Tahu Dengan Bioaktivator Mol Tape Singkong Hasil analisis tanah dan pupuk organik limbah ampas tahu dengan bioaktivator mol tape singkong yang dilakukan di Balai Riset dan Standardisasi Industri Palembang (Baristand)

Tabel 1. Kandungan mikro tanah dan pupuk organik ampas tahu

\begin{tabular}{lcccccl}
\hline \multirow{2}{*}{ Parameter Uji } & Satuan & Tanah & \multicolumn{3}{c}{ Hasil Uji } & \multirow{2}{*}{ Metode Uji } \\
\cline { 4 - 6 } & & & $\mathbf{P 1}$ & $\mathbf{P 2}$ & $\mathbf{P 3}$ & \\
\hline Nitrogen & $\%$ & 0,18 & 0,09 & 0,03 & 0,06 & Titrimetri \\
Fosfor sebagai $\mathrm{P}_{2} \mathrm{O}_{5}$ total & $\%$ & 0,06 & 0,62 & 0,08 & 0,12 & Spektofotometri \\
Kalium sebagai $\mathrm{K}_{20} \mathrm{O}$ & $\%$ & 1,4 & 1,82 & 2,90 & 2,46 & AAS \\
\hline
\end{tabular}

Sumber: Balai Riset dan Standardisasi Industri Palembang (2015).

Analisis tanah dan pupuk organik ampas tahu dengan bioaktivator tape singkong yang dilakuakn di laboratorium balai riset dan standardisasi industri (Baristand) menunjukan bahwa pada tanah yang menjadi media tanam terdapat unsur-unsur seperti Nitrogen 0,18 $\%$, fosfor (sbg P2O5) total 0,06 \%, Kalium (sbg K2O) 1,4\%, sedangkan pada kompos limbah ampas tahu dengan bioaktivator mol tape singkong terdapat unsur-unsur seperti P1 Nitrogen 0,09\%, posfor (sbg P2O5) total 0,62\%, Kalium (sbg K2O) 1,82 \%, P2 Nitrogen $0,03 \%$, posfor (sbg P2O5) total 0,08 \%, Kalium (sbg K2O) 2,90\%, P3 Nitrogen 0,06\%, posfor (sbg P2O5) total 0,12 \%, Kalium (sbg K2O) $2,46 \%$.

\section{Tinggi Batang tanaman Kangkung Darat (Ipomoea reptans)}

Dari hasil analisis sidik ragam bahwa pada tabel 1. F-hitung perlakuan 2,796 lebih kecil dibanding F tabel 0,05 $(3,29)$ dan F tabel 0,01 $(5,42)$,ini berarti bahwa perlakuan pupuk organik limbah ampas tahu dengan bioaktivator mol tape singkomg berpengaruh nyata terhadap tinggi tanaman Kangkung Darat (Ipomoea reptans). 
Tabel 2. Analisis Sidik Ragam Tinggi Tanaman Kangkung Darat (Ipomoea reptans)

\begin{tabular}{lcccccc}
\hline $\begin{array}{c}\text { Sumber } \\
\text { keragaman } \\
\text { (SK) }\end{array}$ & $\begin{array}{c}\text { Derajat } \\
\text { Bebas (DB) }\end{array}$ & $\begin{array}{c}\text { Jumlah } \\
\text { Kuadrat } \\
\text { (JK) }\end{array}$ & $\begin{array}{c}\text { Kuadrat } \\
\text { Tengah (KT) }\end{array}$ & F hitung & $\mathbf{0 , 0 5}$ & $\mathbf{0 , 0 1}$ \\
\hline Perlakuan & 3 & 58,86 & 19,62 & $2,769 *$ & 3,29 & 5,42 \\
Kelompok & 5 & 118,51 & 23,70 & 3,345 tn & 2,90 & 4,56 \\
Galat & 15 & 106,28 & 7,08 & & & \\
Total & 23 & 283,65 & &
\end{tabular}

Selanjutnya untuk mengetahui pengaruh dari setiap perlakuan diuji lanjut berupa uji beda nyata terkecil (BNT) terhadap tinggi tanaman kangkung darat (Ipomoea reptans).

Hasil uji BNT tinggi tanaman kangkung darat (Ipomoea reptans) pada tabe 3, menunjukkan pada perlakuan P1 berbeda nyata terhadap perlakuan P1, P2, dan P3.

Tabel 3. Hasil Uji Beda Nyata (BNT) Terhadap Tinggi TanamanKangkung Darat (Ipomoea reptans)

\begin{tabular}{cccccccc}
\hline \multirow{2}{*}{ Perlakuan } & \multirow{2}{*}{ Rata-rata } & \multicolumn{7}{c}{ Beda Rata-rata } & \multicolumn{2}{c}{ BNT } \\
\cline { 3 - 8 } & & P1 & P2 & P3 & P0 & $\mathbf{0 , 0 1}$ & $\mathbf{0 , 0 5}$ \\
\hline P0 & 17,56 & $4,31^{*}$ & 2,4 & 1,47 & - & 4,52 & 3,27 \\
P3 & 19,47 & 2,84 & 0,93 & - & - & - \\
P2 & 20,40 & 1,91 & - & - & - & \\
P1 & 21,87 & - & - & - &
\end{tabular}

3. Jumlah Daun tanaman Kangkung Darat (Ipomoea reptans)

Berdasarkan pada hasil Analisis Sidik Ragam (Ansira) pada tabel 4, dapat dilihat bahwa pupuk organik limbah ampas tahu dengan bioaktivator mol tape singkong berpengaruh sangat nyata terhadap pertambahan jumlah daunKangkung Darat (Ipomoea reptansL.). Pada F hitung perlakuan adalah 6,284 lebih besar dibanding $\mathrm{F}$ tabel 0,05 $(3,29)$ dan F tabel 0,01 $(5,42)$.

Tabel 4. Analisis Sidik Ragam Jumlah Daun Tanaman Kangkung Darat (Ipomoea reptans)

\begin{tabular}{ccccccc}
\hline $\begin{array}{c}\text { Sumber } \\
\text { keragaman (SK) }\end{array}$ & $\begin{array}{c}\text { Derajat } \\
\text { Bebas (DB) }\end{array}$ & $\begin{array}{c}\text { Jumlah } \\
\text { Kuadrat } \\
\text { (JK) }\end{array}$ & $\begin{array}{c}\text { Kuadrat } \\
\text { Tengah (KT) }\end{array}$ & F hitung & \multicolumn{2}{c}{ F tabel } \\
\hline Perlakuan & 5 & 8,282 & 2.760 & $6,284^{* *}$ & 3,29 & 5,42 \\
Kelompok & 3 & 21,25 & 4,251 & 9,676 tn & 2,90 & 4,56 \\
Galat & 15 & 6,589 & 0,439 & & \\
Total & 23 & 36,121 &
\end{tabular}

Selanjutnya untuk mengetahui pengaruh dari setiap perlakuan diuji lanjut berupa uji beda nyata terkecil (BNT) terhadap tinggi tanaman kangkung darat (Ipomoea reptans). Hasil uji BNT jumlah daun tanaman kangkung darat (Ipomoea reptans) pada tabel 5, menunjukkan 
pada perlakuan P1 berbeda sangat nyata perlakuan P2 dan P3 berbeda nyata terhadap terhadap P2, P3, dan P0. Sedangkan pada P1.

Tabel 5. Hasil Uji Beda Nyata (BNT) Terhadap Jumlah Daun Tanaman Kangkung Darat (Ipomoea reptans)

\begin{tabular}{cccccccc}
\hline \multirow{2}{*}{ Perlakuan } & \multirow{2}{*}{ Rata-rata } & \multicolumn{7}{c}{ Beda Rata-rata } & \multicolumn{2}{c}{ BNT } \\
\cline { 3 - 7 } & & P1 & P2 & P3 & P0 & $\mathbf{0 , 0 1}$ & $\mathbf{0 , 0 5}$ \\
\hline P0 & 11,15 & $1,6^{* *}$ & $0,98^{*}$ & $0,55^{*}$ & - & 1,12 & 0,18 \\
P3 & 11,70 & $1,05^{*}$ & $0,43^{*}$ & - & - & \\
P2 & 12,13 & $0,62^{*}$ & - & - & - & \\
P1 & 12,75 & - & - & - & - & \\
\hline \multicolumn{7}{c}{ Keterangan: }
\end{tabular}

4. Lebar Daun tanaman Kangkung Darat darat (Ipomoea reptans). Analisis Sidik Ragam (Ipomoea reptans)

Dari hasil Analisis Sidik Ragam pupuk (Ansira) pada tabel 6 menunjukkan bahwa organik ampas tahu dengan bioaktivator dibanding F tabel $0,05(3,29)$ dan F tabel 0,01 mol tape singkong berpengaruh sangat nyata $(5,42)$. terhadap pertumbahan jumlah daun kangkung

Tabel 6. Analisis Sidik Ragam Lebar Daun Tanaman Kangkung Darat (Ipomoea reptans)

\begin{tabular}{|c|c|c|c|c|c|c|}
\hline \multirow{2}{*}{$\begin{array}{c}\text { Sumber } \\
\text { keragaman (SK) }\end{array}$} & \multirow{2}{*}{$\begin{array}{c}\text { Derajat } \\
\text { Bebas (DB) }\end{array}$} & \multirow{2}{*}{$\begin{array}{l}\text { Jumlah } \\
\text { Kuadrat } \\
\text { (JK) }\end{array}$} & \multirow{2}{*}{$\begin{array}{c}\text { Kuadrat } \\
\text { Tengah (KT) }\end{array}$} & \multirow{2}{*}{ F hitung } & \multicolumn{2}{|c|}{ F tabel } \\
\hline & & & & & 0,05 & 0,01 \\
\hline Perlakuan & 3 & 3,671 & 1,223 & $17,40^{* *}$ & 3,29 & 5,42 \\
\hline Kelompok & 5 & 0,824 & 0,164 & $2,343 \mathrm{tn}$ & 2,90 & 4,56 \\
\hline Galat & 15 & 1,055 & 0,070 & & & \\
\hline Total & 23 & 5,550 & & & & \\
\hline
\end{tabular}

Selanjutnya untuk mengetahui pengaruh dari setiap perlakuan diuji lanjut berupa uji beda nyata terkecil (BNT) terhada lebar daun tanaman kangkung darat (Ipomoea reptans). Dari hasil uji BNT pada tabel 7, menunjukkan pada perlakuan P1 dan P2 berbeda sangat nyata terhadap perlakuan P3 dan P0. Sedangkan pada perlakuan P3 berbeda tidak nyata terhadap perlakuan P0.

Tabel 7. Hasil Uji Beda Nyata (BNT) Terhadap Lebar Daun Kangkung Darat (Ipomoea reptans)

\begin{tabular}{|c|c|c|c|c|c|c|c|}
\hline \multirow{2}{*}{ Perlakuan } & \multirow[t]{2}{*}{ Rata-rata } & \multicolumn{4}{|c|}{ Beda Rata-rata } & \multicolumn{2}{|c|}{ BNT } \\
\hline & & P1 & P2 & P3 & P0 & 0,01 & 0,05 \\
\hline P0 & 2,35 & $0,96^{* *}$ & $0,49^{* *}$ & $0,04^{\text {tn }}$ & - & 0,45 & 0,32 \\
\hline P3 & 2,82 & $0,92^{* *}$ & $0,45^{*}$ & - & - & & \\
\hline P2 & 3,27 & $0,47^{* *}$ & - & - & - & & \\
\hline P1 & 3,31 & - & - & - & - & & \\
\hline
\end{tabular}


Panjang Daun tanaman Kangkung Darat (Ipomoea reptans)

Berdasarkan hasil analisis Sidik Ragam (Ansira) pada tabel 8 menunjukkan bahwa F hitung perlakuan adalah 6,935 lebih besar dibanding $\mathrm{F}$ tabel $0,05(3,29)$ dan $\mathrm{F}$ tabel
0,01 $(5,42)$. Dari hasil perbandingan tersebut ternyata bahwa perlakuan $\mathrm{p}$ media tanam tanah dan pupuk organik ampas tahu dengan biaktivator mol tape singkong berpengaruh sangat nyata terhadap panjang daun tanaman kangkung darat (Ipomoea reptans).

Tabel 8. Analisis Sidik Ragam Panjang Daun Tanaman Kangkung Darat (Ipomoea reptans)

\begin{tabular}{|c|c|c|c|c|c|c|}
\hline \multirow{2}{*}{$\begin{array}{c}\text { Sumber } \\
\text { keragaman } \\
\text { (SK) }\end{array}$} & \multirow{2}{*}{$\begin{array}{c}\text { Derajat } \\
\text { Bebas (DB) }\end{array}$} & \multirow{2}{*}{$\begin{array}{c}\text { Jumlah } \\
\text { Kuadrat } \\
\text { (JK) }\end{array}$} & \multirow{2}{*}{$\begin{array}{c}\text { Kuadrat } \\
\text { Tengah (KT) }\end{array}$} & \multirow{2}{*}{ F hitung } & \multicolumn{2}{|c|}{ F tabel } \\
\hline & & & & & 0,05 & 0,01 \\
\hline Perlakuan & 3 & 10,126 & 3,375 & $6,935 * *$ & 3,29 & 5,42 \\
\hline Kelompok & 5 & 20,022 & 4,004 & $8,227 \mathrm{tn}$ & 2,90 & 4,56 \\
\hline Galat & 15 & 7,300 & 0,486 & & & \\
\hline Total & 23 & & & & & \\
\hline
\end{tabular}

Selanjutnya untuk mengetahui pengaruh dari setiap perlakuan diuji lanjut berupa uji beda nyata terkecil (BNT) terhadap panjang daun tanaman kangkung darat (Ipomoea reptans). Hasil uji BNT panjang daun tanaman kangkung darat (Ipomoea reptans) pada tabel 8, menunjukkan perlakuan P1 berbeda sangat nyata terhadap perlakuan P2, P3, dan P0. Sedangkan pada perlakuan P2 dan P3 berbeda nyata tidak nyata terhadap perlakuan $\mathrm{P} 1$.

Tabel 9. Hasil Uji Beda Nyata (BNT) Terhadap Panjang Daun TanamanKangkung Darat (Ipomoea reptans)

\begin{tabular}{|c|c|c|c|c|c|c|c|}
\hline \multirow{2}{*}{ Perlakuan } & \multirow[t]{2}{*}{ Rata-rata } & \multicolumn{4}{|c|}{ Beda Rata-rata } & \multicolumn{2}{|c|}{ BNT } \\
\hline & & P1 & P2 & P3 & P0 & 0,01 & 0,05 \\
\hline P0 & 8,315 & $1,595^{* *}$ & $0,594^{\text {tn }}$ & $0,474^{\text {tn }}$ & - & 1,186 & 0,858 \\
\hline P3 & 9,68 & $1,485^{* *}$ & $0,12^{\text {tn }}$ & - & - & & \\
\hline P1 & 9,80 & $1,365^{* *}$ & - & - & - & & \\
\hline P2 & 9,91 & - & - & - & - & & \\
\hline
\end{tabular}

\section{Pembahasan}

\section{Pembahasan Analisis Tanah Dan Pupuk Organik Ampas Tahu Dengan Bioaktivator Mol Tape Singkong}

Analisis tanah dan pupuk organikampas tahu dengan bioaktivator mol tape singkong yang dilakuakn di laboratorium balai riset dan standardisasi industri (Baristand) menunjukan bahwa pada tanah yang menjadi media tanam terdapat unsur-unsur seperti Nitrogen 0,18\%, fosfor $\left(\operatorname{sbg} \mathrm{P}_{2} \mathrm{O}_{5}\right)$ total $0,06 \%$, Kalium $\left(\operatorname{sbg} \mathrm{K}_{2} \mathrm{O}\right)$ $1,4 \%$, sedangkan pada kompos limbah ampas tahu dengan bioaktivator mol tape singkong terdapat unsur-unsur seperti P1 Nitrogen 0,09 $\%$, posfor ( $\operatorname{sbg} \mathrm{P}_{2} \mathrm{O}_{5}$ ) total 0,62\%, Kalium (sbg $\left.\mathrm{K}_{2} \mathrm{O}\right) 1,82 \%$, P2 Nitrogen 0,03\%, posfor (sbg $\mathrm{P}_{2} \mathrm{O}_{5}$ ) total 0,08 \%, Kalium (sbg $\left.\mathrm{K}_{2} \mathrm{O}\right) 2,90 \%$, P3 Nitrogen $0,06 \%$, posfor $\left(\operatorname{sbg} \mathrm{P}_{2} \mathrm{O}_{5}\right)$ total $0,12 \%$, Kalium (sbg $\left.\mathrm{K}_{2} \mathrm{O}\right) 2,46 \%$. Unsurunsur yang terdapat pada pupuk organik limbah ampas tahu sangat berperan penting terhadap pertumbumhan tanaman, tidak terkecuali tanaman kangkung darat (Ipomoea reptans L.) dimana unsur nitrogen $(\mathrm{N})$ pada $\mathrm{P} 1$ sebesar 0,09\%,P2 sebesar 0,03\%,dan P3 sebesar 0,06 
\% yang berperan dalam pembentukan atau pertumbuhan bagian vegetatif tanaman, seperti daun, batang dan akar, berperan penting dalam hal pembentukan zat hijau daun yang berguna sekali dalam proses fotosintesis, meningkatkan mutu tanaman penghasil daun-daunan dan meningkatkan perkembangan mikroorganisme di dalam tanah.

Unsur fosfor $(\mathrm{P})$ yang berperan penting dalam transfer energi di dalam sel tanaman, mendorong perkembangan akar dan pembuahan lebih awal, memperkuat batang sehingga tidak mudah rebah, serta meningkatkan serapan $\mathrm{N}$ pada awal pertumbuhan. Unsur kalium $(\mathrm{K})$ juga sangat berperan dalam pertumbuhan tanaman misalnya untuk memacu translokasi karbohidrat dari daun ke organ tanaman (Syafrudin et al, 2012).

ketersediaan unsur hara yang cukup dan seimbang akan mempengaruhi proses metabolisme pada jaringan tanaman. Proses metabolisme merupakan pembentukan dan perombakan unsur-unsur hara dan senyawa organik dalam tanaman. Sebaliknya Lebih kekurangan unsur hara pada tanaman dapat memperhambat proses pertumbuhan pada tanaman itu sendiri.

\section{Tinggi Batang tanaman Kangkung Darat (Ipomoea reptans)}

Dari hasil aanalisis bahwa F-hitung 2,769 lebih kecil dibanding $\mathrm{F}$ tabel $0,05(3,29)$ dan $\mathrm{F}$ tabel $0,01(5,42)$, ini berarti bahwa perlakuan respon pupuk organik limbah ampas tahu dengan bioaktivator mol tape singkongberpengaruh nyata terhadap tinggi tanaman Kangkung Darat (Ipomoea reptans). untuk melihat perbedaan antar perlakuan, maka dilakukan analisis lanjut Hasil Uji Beda Nyata (BNT). Sedangkan hasil uji BNT data yang didapat dari perlakuan P0 menunjukkan berbeda sangat nyata dengan $\mathrm{P} 1$, P2, dan P3. P1 berbeda nyata dengan P2 dan P3.

Menurut hasil penelitian Wasis (2010), pemberian pupuk NPK 10 gram memberikan pengaruh paling nyata terhadap tinggi tanaman dengan peningkatan pertumbuhan tinggi sebesar 109,72 \% dibandingkan kontrol. Pemberian kompos berpengaruh nyata terhadap pertumbuhan tinggi tanaman kangkung darat (Ipomoea reptans) hal itu disebabkan karena pemberian kompos disamping meningkat kadar hara tanah juga memperbaiki sifat fisik tanah. Kerena semakin meningkatkan kadar perbandingan pupuk organik akan menmperbaiki sifat fisik pada tanah sehingga tanaman akan menyerap air dan nutrisi dengan baik.

\section{Jumlah Daun tanaman Kangkung Darat (Ipomoea reptans)}

Perlakuan respon pupuk organik ampas tahu dengan bioaktivator mol tape singkongberpengaruh sangat nyata terhadap pertumbuhan dan perkembangan tanaman Kangkung Darat (Ipomoea reptans). Dimana hal tersebut berdasarkan pada hasil Analisis Sidik Ragam (Ansira) pada Tabel 4.7 dapat dilihat bahwa pupuk organik limbah ampas tahu dengan bioaktivator mol tape singkongberpengaruh sangat nyata terhadap pertambahan jumlah daunKangkung Darat (Ipomoea reptans). Pada $\mathrm{F}$ hitung perlakuan adalah 6,284 lebih besar dibanding $F$ tabel 0,05 $(3,29)$ dan $F$ tabel $0,01(5,42)$. untuk melihat perbedaan antar perlakuan, maka dilakukan analisis lanjut Hasil Uji Beda Nyata (BNT). Hasil uji BNT menunjukkan kepada perlakuan P0 berbeda sangat nyata dengan P1, P2, dan P3. P1 berbeda sangat nyata dengan P2 dan P3. P2 berbeda nyata dengan P1 dan P3.

Pertumbuhan jumlah daun sejalan dengan bertambahnya umur tanaman. Semakin tua suatu tanaman maka makin banyak tunas yang muncul sehingga jumlah daun semakin banyak (Salamah, 2013). Jumlah daun pada tanaman berfungsi sebagai organ utama fotosintesis, kemudian umur pada daun dapat mempengaruhi proses fotosintesis, karena proses penuaan pada daun menyebabkan kelambanan terjadinnya proses fotosintesis. Kekurangan klorofil pada tanaman akan 
menyebabkan daun menguning dan proses pertumbuhan tanaman akan menjadi lambat sehingga tanaman menjadi kerdil.

\section{Lebar Daun tanaman Kangkung Darat (Ipomoea reptans)}

Dari hasil Analisis Sidik Ragam pupuk organik limbah ampas tahu dengan bioaktivator mol tape singkongberpengaruh sangat nyata terhadap pertambahan jumlah daunKangkung Darat (Ipomoea reptans).Analisis Sidik Ragam (Ansira) pada tabel 4.9 menunjukkan bahwa F hitung perlakuan adalah 17,40 lebih besar dibanding $\mathrm{F}$ tabel $0,05(3,29)$ dan $\mathrm{F}$ tabel $0,01(5,42)$, untuk melihat perbedaan antar perlakuan, maka dilakukan analisis lanjut Hasil Uji Beda Nyata (BNT. Hasil uji BNT menunjukkan kepada perlakuan P0 berbeda sangat nyata dengan P1, P2, dan P3. P1 berbeda sangat nyata dengan P2 dan P3. P2 berbeda sangat nyata dengan P1 dan P3. P3 berbeda tidak nyata dengan P1 dan P2.

Menurut hasil penelitian Ovianty et al (2016) hasil analisis sidik ragam menunjukkan bahwa pupuk organik cair daun gamal berpengaruh nyata terhadap lebar daun tanaman sawi. Daun berfungsi dalam proses fotosintesis dan Kekurangan Kalium pada tanaman dapat menyebabkan daun mengerut atau mengeriting terutama pada daun yang sudah tua kemudian ketersediaan unsur nitrogen yang cukup akan membantu mempercepat proses fotosintesis sehingga pembentukan organ daun menjadi lebih cepat.

\section{Panjang Daun tanaman Kangkung Darat (Ipomoea reptans)}

Dari hasil Analisis Sidik Ragam bahwa pupuk organik limbah ampas tahu dengan bioaktivator mol tape singkongberpengaruh sangat nyata terhadap pertambahan jumlah daunKangkung Darat (Ipomoea reptans). Analisis Sidik Ragam (Ansira) pada tabel 4.11 menunjukkan bahwa $\mathrm{F}$ hitung perlakuan adalah 6,935 lebih besar dibanding $F$ tabel 0,05 $(3,29)$ dan $F$ tabel $0,01(5,42)$, untuk melihat perbedaan antar perlakuan, maka dilakukan analisis lanjut Hasil Uji Beda Nyata (BNT). Hasil uji BNT menunjukkan kepada perlakuan P0 berbeda sangat nyata dengan P1, P2, dan P3. P2 berbeda sangat nyata dengan P1 dan P3. P1 tidak berbeda nyata dengan P2 dan P3. P3 berbeda tidak nyata dengan P1 dan P2.

Unsur nitrogen berfungsi untuk merangsang pertumbuhan tinggi tanaman dan unsur nitrogen dalam jumlah yang cukupberperan dalam mempercepat pertumbuhan tanaman secara keseluruhan khususnya batang dan daun. Unsur nitrogen paling banyak dibutuhkan untuk tanaman kangkung oleh karena itu pupuk organik sangat bermanfaat terhadap pertumbuhan tanaman kangkung darat khususnya pada saat pertumbuhan batang dan daun.Menurut Edi (2014), daun merupakan organ penting bagi tanaman sebagai tempat untuk fotosintesis. Melalui proses fotosintesis maka akan terjadi pembentukan karbohidrat. Peningkatan jumlah daun menunjukkan peningkatan secara Kuantitatif seiring dengan meningkatnya umur tanaman yang berhubungan dengan perkembangan sel.

Menurut penelitian (sarwono dan prayono, 2015), pegaruh perlakuan bobot abu vulkan dan dosis pupuk organik tidak nyata terhadap panjang daun tanaman kangkung darat. Kemudian untuk mengetahui pangaruh lebih lanjut digunakan uji jarak berganda Duncan pada taraf nyata 5\%. Hal ini menunjukkan bahwa kandungan $\mathrm{N}$.

\section{Kesimpulan}

Berdasarkan hasil penelitian yang telah dilakukan maka di simpulkan bahwa, pupuk organik ampas tahu dengan bioaktivator mol tape singkong dengan konsentrasi yang berbeda dan dari hasil uji beda nyata (BNT) pada perlakuan P0,P1,P2, dan P3 menujukkan berbeda sangat nyata terhadap tinggi,jumlah daun, lebar daun, dan panjang daun pada tanaman kangung darat (Ipomoea reptans). 


\section{Daftar Pustaka}

Edi Syafri,2014. Pengaruh Pemberian Pupuk Organik Terhadap Pertumbuhan Dan Hasil Tanaman Kangkung Darat (Ipomoea reptans). 3 (1):ISSN 2302-6472

Lutfi Setyo Wibowo, 2011. Taraf Penggunaan Mikroorganisme Lokal Tapai Sebagai Bioaktivator Pembuatan Pupuk Organik Campuran Kotoran Domba Dengan Batang Pisang.

Melati,.M,. dan Andriyani,.W.2005. Pengaruh Pupuk Kandang Ayam dan Pupuk Hijau Calopogonium Mucunoldes Terhadap Pertumbuhan dan Produksi Kedelai Panen Muda Yang Dibudidayakan Secara Organik. 33(2):8-15 hlm.

Marpaung,A,E.2014. pemanfaatan Pupuk Organik Padat Dan Pupuk Organik Cair Dengan Pengurangan Pupuk Anorganik Terhadap Pertumbuhan Tanaman Jagung, jurnal saintech. 6 (4):ISSN 2086-9681.

Ovianty.,F., Syarifah dan Hidayah.,N. 2016. Pengaruh Pemberian Pupuk Organik Cair Daun Gamal (Gliricidia sepium (Jacq) Kunth ex Walp.) Terhadap Pertumbuhan Tanman Sawi, Jurnal Biota. 2(1):61 hlm.

Rachman,.A,.I,.Djuniwati,.S dan Idris,.K.2008. Pengaruh Bahan Organik dan Pupuk NPK Terhadapn Serapan Hara dan Produksi Jagung di Inceptisol Ternate,Jurnal Tanah Dan Lingkungan. 10 (1):7-13 hlm.

Rodiah.,S.,I.2013. Manfaat Penggunaan Pupukorganik Untuk Kesuburan Tanah, Jurnal Universitas Tulungagung Bonorowo. 1 (1).

Salamah.,Z.,I.2013. Pertumbuhan Tanaman Kangkung Darat (Ipomoea Reptans) Dengan Pemberian Pupuk Organik Berbahan Dasar Kotoran Kelinci, Jurnal Bioedukatika. 1(1):1-96 hlm.

Syafrudin.,Nurhayati dan Wati.,R. 2012. Pengaruh Jenis Pupuk Terhadap Pertumbuhan Dan Hasil Beberapa Varietas Jagung Manis, Jurnal Floratek. 107-114 hlm.

Wasis.,B dan Fathia.,N. 2010. Pengaruh Pupuk NPK Terhadap Pertumbuhan Semai Gmelina (Gmelina arborea roxb.) Pada Media Tanah Bekas Tambang Emas (Tailings), Jurnal Ilmu Pertanian Indonesia. 15 (2):123-129 hlm. 